\title{
EL QUIJOTE ANTES DEL CINEMA: FILMOLITERATURA
}

\author{
Darío VILLANUEVA \\ Madrid: Visor Libros, 2020, 356 pp. \\ ISBN: 9788498952360
}

Reseñar el libro que recoge los más destacados estudios de Filmoliteratura del profesor Darío Villanueva - mostrando desde el título la humildad científica, el rigor y la alambicada precisión de las investigaciones, el discurso y la escritura de su autor, al recoger con máximo respeto historiográfico el término acuñado en su día por Joaquín Entrambasaguas a la hora de poner en pie en la más cruda posguerra española (a partir del curso 1944-1945) una asignatura así denominada en la Facultad de Filosofía y Letras de la Universidad de Madrid - constituye un auténtico honor para quien tuvo la fortuna de que tan eminente figura de la filología española, entonces Rector de la USC y mucho más tarde Director de la Real Academia Española, presidiese en 1997 el tribunal que juzgó en Compostela su tesis doctoral y comparte hoy codo con codo con él la gestión del CEFILMUS (Centro de Estudios Fílmicos de la Universidad de Santiago), que el propio Villanueva contribuyera a poner en marcha en su día.

La tan precisa como extensa introducción del volumen ("Cinefilia española y Filmoliteratura. El Precinema”, en realidad núcleo auténticamente esencial del mismo) traza de forma tan decidida como detallada, en buena medida a partir de su discurso de ingreso en la Real Academia Española (2008) — y sin renunciar a lo que en su sentida respuesta a ese mismo discurso Pere Gimferrer calificara cómo "aparentes bifurcaciones y meandros" sin embargo no serpenteantes ni zigzagueantes, sino capaces de reforzar una unidad profunda, tan creativa como rigurosa, construida "a un tiempo de pasión, empeño y lucidez" (Gimferrer dixit) —, la triple apoyatura sobre la que este se sustenta teórica e historiográficamente y nos va a permitir, por tanto, estructurar nuestra reseña en torno a ella.

En primer lugar, el concepto, acuñado por el propio Villanueva, de "cinefilia española", que parte del interés por el cine de algunos escritores españoles del 98 como Azorín o Valle-Inclán y de su temprana valoración del mismo como "cauce de inagotables posibilidades expresivas fundamental para la sensibilidad contemporánea", sin que por ello desconozcan que buena parte de dichas posibilidades estaban presentes ya - aunque, obvio es, a través de mecanismos formales diferentes y sin alcanzar la visualidad 
espectacular del montaje cinematográfico ${ }^{1}$ - en el teatro y la novela desde siglos precedentes. Aunque la obra del propio Valle-Inclán —ese sincretismo experimental del escritor gallego capaz de aprovechar y fusionar teatro, narración novelesca y cine que será el objeto central del Capítulo 3 -se desarrolla ya en el siglo del cine, nuestros filólogos más relevantes — con Ramón Menéndez Pidal a la cabeza — investigan también desde muy temprano la presencia de elementos que anticipan el cinematógrafo (la discontinuidad y lo fragmentario, las "impresiones entrecortadas, dispares y episódicas", su aceleración y claroscuro...) en dramaturgos como Tirso de Molina o Lope de Vega. Esta confluencia del interés por el cine desde varios campos de la creación y del saber, este cada vez más sabroso caldo de cultivo que tomaba cuerpo en nuestra "Edad de Plata", va a convertir a España, señala el autor, en una "de las repúblicas literarias en la que los nexos entre cine y literatura se trenzaron más intensamente desde finales de los años diez", dando lugar a un cúmulo de realizaciones — que van desde la obra del propio ValleInclán a las criticas cinematográficas de Francisco Ayala en Revista de Occidente y la publicación de su Indagación del cinema (1929); desde el número monográfico dedicado al séptimo arte por La Gaceta Literaria (octubre, 1928) o la creación del Cine Club Español en el entorno de la Residencia de Estudiantes al inicio de una tesis doctoral sobre el lenguaje del cine por parte de Gonzalo Menéndez Pidal y no concluida por culpa del estallido de la Guerra Civil) — cuyas fértiles consecuencias ni siquiera el trágico conflicto bélico será capaz, contra todo pronóstico, de destruir. Así lo demuestran fehacientemente la puesta en marcha de la ya citada asignatura Filmoliteratura en la universidad madrileña de mediados de los años 40, la fundación de la Asociación Española de Filmología poco después o el nacimiento del decisivo Instituto de Investigaciones y Experiencias cinematográficas (más tarde Escuela Oficial de Cine) en 1947.

Y precisamente entre los intereses de esa Filmoliteratura - que se incorpora de inmediato al programa curricular de un IIEC en el que entonces destacan alumnos como Juan Antonio Bardem y Luis García Berlanga ${ }^{2}$ - es ya evidente la citada preocupación

\footnotetext{
${ }^{1} \mathrm{Y}$, de hecho, el montaje cinematográfico tendrá que aprender a utilizarlas durante el tan fascinante como complejo periodo denominado "primitivo" o de los primeros tiempos (1895-1906), en el que, en principio, apenas balbuceará filmes de algunos planos basados en las más simples persecuciones, hasta que los cineastas sean capaces de incorporar al nuevo medio, por medio de imágenes, la belleza y la expresividad de esas obras literarias precedentes. Villanueva, con lógica, parte ya de un momento posterior en el que los maestros del cine silente, y en especial David W. Grifftih y Sergei. M. Eisenstein, logran articular sobre la pantalla historias a partir de la conversión en materia fílmica de ciertos recursos narrativos (y "visuales") de grandes novelistas como, entre otros, Charles Dickens (a cuya influencia que ambos directores se refieren explícitamente en varios momentos).

${ }^{2}$ Me permito señalar aquí que, por fortuna, los estudios filmoliterarios del profesor Villanueva todavía habrán de darnos sustanciosas lecciones en el futuro. Con seguridad el más próximo ha de ser el capítulo "Berlanga en la cultura española: cinefilia y esperpento" que forma parte del volumen (Furia española. Vida, obra, opiniones y milagros de Luis García Berlanga [1921-2010], cineasta, bajo la dirección de Santos Zunzunegui y J. L. Castro de Paz) con el que Filmoteca Española y Filmoteca Valenciana conmemoran el centenario del nacimiento del autor de El verdugo (1963) y que sitúa por precisión al maestro valenciano en el contexto del siglo XX español, pero también en el de esa generación del medio siglo, cuyas bases sienta nuestro autor en el brillante capítulo 8 del libro que aquí reseñamos ("El cine en la generación del medio siglo: el neorrealismo literario español").
} 
filológica española por el Precinema — segundo de esos ya citados pilares teóricos e historiográficos que cimentan El Quijote del cinema: Filmoliteratura y eje nuclear del deslumbrante capítulo 1, que de hecho da título al libro - entendido no en su acepción tecnológica sino en otra fundamentalmente estética y artística, centrada en las estructuras y recursos formales que se encuentran en los filmes y que aparecen también en obras literarias previas a 1895, y, por tanto, en problemas que afectan a una narratividad sustanciada mediante diversos medios expresivos a lo largo de la historia de la cultura, y de los que el cine vendría a ser, de algún modo, una especie de culminación. Es pues este peculiar y fructífero análisis que va de la literatura al cine $-\mathrm{y}$ que tanto nos ha ayudado a los historiadores del cine a poner modestamente los pies en el suelo más de una vezel que emprende el profesor Villanueva a partir de la magistral obra cervantina, sin que por ello deje de reparar con la necesaria dilación primero (y con posterioridad, pues el capítulo 2 penetra en una sutil "transformación de la obra literaria", a partir de los Macbeth de Roman Polanski y Harold Bloom) en la de William Shakespeare, "probablemente el clásico al que el cine deba más, incluso antes en términos cualitativos que cuantitativos" (sintaxis de escenas y secuencias que adelanta el desglose del montaje cinematográfico; juego del campo-contracampo consustancial al diálogo, importancia concedida a la visualidad de los cuerpos y los objetos...). El estudio de este no menos sensitivo y en especial visual y auditivo Quijote antes del cinema es de tal rigor, erudición y profundidad que una reseña a la altura del mismo no cabría en el espacio total del que dispongo. Me contentaré con referirme brevemente a dos aspectos en verdad fascinantes, y en los que Darío Villanueva se introduce hasta lo más hondo, logrando desentrañar hasta los motivos y razones estéticas más profundas de tales fenómenos. El primero de ellos, la extrema vocación icónica de la novela de Cervantes, "una de las obras de la literatura mundial que ha suscitado más y mejores écfrasis inversas" (p. 44; concepto acuñado por nuestro autor para referirse a este proceso, inverso al de describir literariamente una obra artística), con el francés Gustave Doré como ejemplo más destacado y célebre, autor de "las imágenes librescas de El Quijote por antonomasia" (p. 69). El segundo, el análisis de los riquísimos aspectos metaficcionales presentes en la "novela de novelas", que, por cierto - y coincido aquí con el autor y con Pere Gimferrer-, es capaz de convertir en material cinematográfico mejor que ninguna otra la excelsa versión española dirigida por Rafael Gil en 1947, con motivo del IV centenario del nacimiento del escritor, filme que, además, parece indagar incluso en el "origen" de esa "écfrasis inversa" propuesta por Villanueva, pues a la búsqueda de una versión escrupulosamente respetuosa, humana y "realista" - la "edición príncipe" de la inmortal obra de Cervantes en el séptimo arte-, Gil decide aproximarse hasta el personaje "vivo y real" encarnado por Rafael Rivelles para, de inmediato - por medio de elaborados reencuadres o juegos lumínicos y sombras esbatimentadas - "fijarlo iconográficamente" con todo lujo a su alcance, a partir de la más reputada tradición iconográfica (con el propio Doré a la cabeza).

En fin, la tercera gran apoyatura del volumen es la que le aporta la ya sólida tradición de unos estudios filmoliterarios que, siempre aferrado al tránsito que va de la literatura al 
cine (y no al revés, reafirmando una y otra vez, con meticulosidad extrema, su condición de "filólogo cinéfilo"), tienen en nuestro autor, precisamente, uno de sus más destacados representantes en el panorama académico internacional. El análisis comparado de la narrativa literaria en La colmena de Cela y la narrativa fílmica en la de Mario Camus es especialmente enjundiosa (Capítulo 7), pero no lo es menos la aproximación al estudio de dos obras tan diferentes - estéticamente casi antagónicas - como La familia de Pascual Duarte (Cela, 1942) y Pascual Duarte (Ricardo Franco, 1975), que indaga, por ejemplo y entre otras muchas cuestiones, en los mecanismos que contribuyen a dirigir discursivamente el filme hacia territorios sociales y políticos no presentes del mismo modo en la novela del escritor gallego y que tenían mucho que ver con el convulso presente histórico de la escritura del guion - que nuestro autor analiza asimismo con rigor, como texto "intermedio" entre novela y película-y del rodaje (Capítulo 6). Estas y otras lecturas filmoliterarias tanto o más enjundiosas - a partir del estudio obras de autores como Thomas Mann, Gabriel García Márquez o Javier Cercas convertidas luego en textos cinematográficos de destacados cineastas - completan un volumen de singular trascendencia no solo para la Filmoliteratura en particular y la Filología en general, sino también para los historiadores y analistas cinematográficos que, como el autor de las líneas que aquí concluyen, han encontrado muchas veces en los textos de Darío Villanueva nuevas y más ricas vetas y formas de adentrarse en el fascinante mundo de la séptima de las artes.

José Luis Castro de Paz Universidad de Santiago de Compostela / CEFILMUS

This work is licensed under a Creative Commons AttributionNonCommercial-NoDerivatives 4.0 International (CC BY-NC-ND). 